\title{
Paranasal Sinus Inverted Papilloma
}

National Cancer Institute

\section{Source}

National Cancer Institute. Paranasal Sinus Inverted Papilloma. NCI Thesaurus. Code C8195.

A benign neoplasm that arises from the ciliated respiratory mucosa that lines the paranasal sinuses. It results from the invagination and proliferation of epithelial cells in the underlying stroma. 